\title{
Drivers of cropland abandonment in mountainous areas: A household decision model on farming scale in Southwest China
}

\author{
Jianzhong Yan ${ }^{\mathrm{a}, *}$, Ziyan Yang ${ }^{\mathrm{b}}$, Zanhong $\mathrm{Li}^{\mathrm{a}}$, Xiubin $\mathrm{Li}^{\mathrm{c}}$, Liangjie Xin ${ }^{\mathrm{c}}$, Laixiang Sun ${ }^{\mathrm{d}, \mathrm{e}, * *}$ \\ a College of Resources and Environment, Southwest University, Chongqing 400716, China \\ b Department of Agricultural and Resource Economics, University of Maryland, College Park, MD, USA \\ ' Institute of Geographic Sciences and Natural Resources Research, CAS, Beijing 100101, China \\ d Department Geographical Sciences, University of Maryland, College Park, MD, USA \\ e International Institute for Applied Systems Analysis, Laxenburg, Austria
}

\section{A R T I C L E I N F O}

\section{Article history:}

Received 4 July 2014

Received in revised form 8 June 2016

Accepted 13 June 2016

Available online 21 June 2016

\section{Keywords:}

Cropland abandonment

Household decision model

Opportunity cost of farming

China

\begin{abstract}
A B S T R A C T
Cropland abandonment has emerged as a prevalent phenomenon in the mountainous areas of China. While there is a general understanding that this new trend is driven by the rising opportunity cost of rural labor, rigorous theoretical and empirical analyses are largely absent. This paper first develops a theoretical model to investigate household decisions on farming scale when off-farm labor market is accessible and there is heterogeneity of farmland productivity and distribution. The model is capable of explaining the hidden reasons of cropland abandonment in sloping and agriculturally less-favored locations. The model also unveils the impacts of heterogeneity of household labor on fallow decisions and the efficiency loss due to an imperfect labor market. The model is empirically tested by applying the Probit and Logit estimators to a unique household and land-plot survey dataset which contains 5258 plots of 599 rural households in Chongqing, a provincial level municipality, in Southwest China. The survey shows that more than $30 \%$ of the sample plots have been abandoned, mainly since 1992 . The econometric results are consistent with our theoretical expectations. This work would help policy-makers and stakeholders to identify areas with a high probability of land abandonment and farming practice which is less sustainable in the mountainous areas.
\end{abstract}

(c) 2016 Elsevier Ltd. All rights reserved.

\section{Introduction}

Cropland abandonment have occurred in West Europe (Gellrich et al., 2007) since the 19th century, then in parts of America since the early 20th century, and later in Southeast Asia (Rhemtulla et al., 2009; Fox et al., 2009). In recent years, this phenomenon has occurred in Eastern Europe and the former Soviet Union (Baumann et al., 2011; Prishchepov et al., 2013). Cropland abandonment is a complex multi-dimensional process with interlinked economic, environmental and social driving forces (Lambin and Meyfroidt, 2010). As such, it has long been a contentious issue worldwide because of difficulties in defining, measuring, monitoring and studying this process (Keenleyside and Tucker, 2010). As a consequence, the current extent and pattern of abandonment in many parts of the world are subject to open debates.

\footnotetext{
* Corresponding author.

** Corresponding author at: Department Geographical Sciences, University of Maryland, College Park, MD, USA

E-mail addresses: yanjzswu@126.com (J. Yan), LSun123@umd.edu (L. Sun).
}

Cropland abandonment exerts mixed effects on economy, society, and ecosystem at both regional and local scales. Documented negative impacts include reduction of landscape heterogeneity (Höchtl et al., 2005), increased fire frequency (Dubinin et al., 2010), soil erosion, reduction of water provisioning (Gallart and Llorens, 2003; Sun et al., 2006), loss of biodiversity and reduced abundance of locally adapted species (Hodges, 2006), and loss of cultural and aesthetic value (Elbakidze and Angelstam, 2007). Documented positive consequences include the passive re-growth of native vegetation and forest plantations (Bonet and Pausas, 2004), water retention (Sileika et al., 2006), soil recovery, improved nutrient cycling and an increase in biodiversity (Benayas et al., 2007; Dunn, 2004).

Cropland abandonment has recently emerged as a noticeable phenomenon in the countryside of China. Although there is no official statistical data yet on cropland abandonment, anecdotal evidence from case studies in many regions indicates that it is widely spreading. A search of the literature on cropland abandonment written in Chinese over the period of 1993-2015 located 245 reports, of which, 47 are based on studies in eastern China, 
170 in central China and 13 in western China. Some of the reports also provide the ratio of abandoned area to the total cropland area of the case-study jurisdiction. The median of the reported ratios for the eastern, central, and western regions was $5.62 \%, 5.7 \%$, and $4 \%$, respectively. ${ }^{1}$ While this literature review does not distinguish mountainous areas from others, one report on mountain area of southern Ningxia province in western China indicates that the abandonment ratio has reached $37.5 \%$ by 2009 in the case study area (Tian et al., 2010).

The most important concern with regard to cropland abandonment in China is its implication to food security given the well-known high scarcity of cropland in the country (Deng et al., 2006; Jiang et al., 2012; Lichtenberg and Ding, 2008; Yan et al., 2009). Every year, urban expansion and the construction of manufacturing centers, highways, railways and other infrastructures occupy a large amount of cropland, especially in eastern China (Liu et al., 2005; Tan et al., 2005; Wang et al., 2012). The 2014 Chinese Land Resources Bulletin, released by the Ministry of Land and Resources of the P. R. China in April 2015, shows that about 160,000 ha of cropland was newly occupied by construction projects in 2014. Floods, desertification and other natural disasters also ruin sizeable amount of croplands. In addition, a large proportion of formerly cultivated sloping croplands have been transferred to woodland and grassland for environmental protection purpose under the "Grain for Green" program. ${ }^{2}$ The above cited Bulletin also reports that cropland loss in 2013 was about 350,000 ha. To counter cropland loss and ensure food security, the Chinese government has invested heavily in basic cropland protection, known as "Jiben nongtian baohu," and in land reclamation, and considerable progress has been made on these two fronts in the last ten years (Government of the People's Republic of China, 2004; Lichtenberg and Ding, 2008).

Against this background, on one hand, it seems that cropland abandonment has run in the wrong direction, being counterproductive and irrational. But on the other hand, the abandonment of marginal lands may facilitate native vegetation recovery, pushing agricultural production to concentrate on cropland with higher productivity and better infrastructure. Therefore, there is an urgent need to have a thorough understanding of the mechanisms and forces which drive cropland abandonment in China. Such an understanding can provide valuable guidance for smart land-use management and planning, balancing the trade-offs between the micro-rationality of farmers in farming intensity decision and macro-rationality for national food security policy design. This paper aims to meet this demand.

It is worth noting that there are ample empirical studies examining the drivers and determinants of cropland abandonment in Europe, Chile, Brazil and other regions (Baumann et al., 2011; Benayas et al., 2007; Díaz et al., 2011; Prishchepov et al., 2013; Renwick et al., 2013; Sikor et al., 2009). These studies indicate that cropland abandonment is a global phenomenon typically driven by rural-urban migration owing to the emergence of new economic opportunities outside farming for rural people, whereas drivers related to ecological conditions and mismanagement are of secondary importance. These new developments raise the opportunity cost of farming and thus reduce the relative profitability of traditional farming businesses. It is also noted that cropland abandonment may occur in areas that are less favorable to agricultural activities because of some restrictions related to ecological con-

\footnotetext{
1 Please note that these are inventory-to-inventory ratio in land use, not growth rate.

2 Under the "Grain for Green" program, the government subsidizes those peasants who fallow their sloping croplands (over $25^{\circ}$ ) for the growing of natural vegetation (Feng et al., 2005; Xu et al., 2007; Groom et al., 2010).
}

ditions and accessibility. The parallel case studies in China also identify that the socio-economic progresses occurring in China have driven rural-to-urban migration and the growing opportunities in urban areas have boosted the cost of labor in rural areas. As a consequence, cropland on which farming activities become too costly is abandoned or converted to other uses (Li and Zhao, 2011; Liu et al., 2005; Liu and Li, 2005; Tian et al., 2009; Zhang et al., 2014).

What distinguish the case of China from others are arguably once again the much higher level of cropland scarcity and much larger rural population per unit of cropland in China. Because of this, China has a longstanding tradition of having a small-scale farming system. For example, a typical farming household in China manages only 0.56 ha of contracted land divided into 9.7 tracts (Dong, 1996; Lin, 1997), an area that is far too small when compared with household farming in Europe and many other countries. In China, the rural-urban migration often occurred seasonally and rural laborers never enjoyed a matched social status with their urban counterparts. In mountainous areas, the hoe and plow still serve as the main tools for agricultural production, although tillers have gradually gained acceptance and have become popular in the plains recently. Thus, a rigorous modeling understanding of forces which drive cropland abandonment dynamics in China must take these unique characteristics of China's small-scale household farming system into account. Zhang et al. (2014) and Li et al. (2014b) made important efforts in this direction.

Zhang et al. (2014) employed a multi-level statistical model to quantify the relationships between the parcel level (natural conditions), household level (household features), and village level (land use activity is more similar within the same village). They applied this model to a dataset of 2011 survey that covers 330 households and 1423 land parcels from 33 villages in Wulong county of Chongqing. Their regression shows that about $80 \%$ of the variance in occurrence of land parcel abandonment can be explained by the natural condition of the individual parcels and only $7 \%$ of the variance can be explained by the features of households, and furthermore, the household features they employed do not have connection with out-migration and wage income from nonagricultural activities. This result is puzzling because of its weak relationship with household decision and lack of connection to out-migration. In other words, the results from such multi-level statistical model cannot explain why the emergence of land abandonment at a significant scale was only a recent phenomenon and has been closely associated with the dynamics of out-migration of major laborers in a household. This puzzle suggests that it is necessary to develop a rigorous theoretical model and use this theoretical model to guide empirical research.

Li et al. (2014b) reported a preliminary attempt to link livelihood strategy of household to cropland abandonment with a simple multivariate linear regression model. It intended to show in a simple way that peasants with different livelihood strategies would make different land use decisions. For example, a household seeking off-farm employment would abandon some parcels of farmland belongs to the household, while a household seeking agricultural intensification strategy would not abandon its cropland. The dependent variable in the simple linear regression is the area abandoned by each household. Therefore, it is not a model at the parcel level. The regression was run on a dataset of 2011 survey that covers 975 households from 12 villages in 3 counties of Chongqing. However, this empirical model suffered from prefect co-linearity and other mis-specification problems such a lack of control for potential spatial interdependence across many households within the same village. As a consequence, the coefficient of the key explanatory variable "percentage of non-agricultural labor" has a wrong sign in 3 of the 4 regressions and are not significant in all 4 regressions; and the coefficient of another key variable "off-farm experience" have contradictory signs in two regressions where it is significant 
(see, Table 8 in Li et al., 2014b). This set of unsatisfactory results also call for a rigorous empirical study based on a theoretically well-grounded and econometrically well-specified model.

In this paper, we develop an agricultural household model of land use choices, in which the household maximizes its utility subject to the constraints of land features, labor and income. In the setting of the model, off-farm labor market is accessible and there is heterogeneity of farmland productivity and distribution. The model aims to explain the underlying reasons of cropland abandonment in sloping and agriculturally less-favored locations. The model also intends to explore the impacts of heterogeneity of household labor on land-use intensity decisions and to calculate the efficiency loss due to an imperfect labor market. The model is tested using Probit and Logit estimators and data from a household and land-plot survey in two counties of Chongqing, a province-level municipality located in Southwest China, in 2012. The carefully consolidated dataset contains 5258 cropland plots of 599 rural households in 8 administrative villages. This plot-based dataset is unique and makes it possible for us to take geophysical, ecological, socioeconomic and agricultural management factors into our modeling setting in an integrated way as strongly appealed by Singh et al. (1986), ${ }^{3}$ and to estimate the abandonment probability of individual land plots. To control for potential spatial interdependence across multiple samples within the same village, we apply the HuberWhite sandwich estimator and estimate robust standard errors.

The rest of the paper is organized as follows. Section 2 introduces the study area and the household and land-plot survey. Section 3 establishes the theoretical model. Section 4 presents the empirical model, estimation methods, and the empirical results. Finally, Section 5 concludes.

\section{Study area and survey method}

Chongqing is a provincial level municipality located in southwest China. It was granted the first-pilot status for the "urban and rural comprehensive reform" in 2007. Chongqing is geographically dominated by mountainous areas, demographically dominated by rural population, and socially characterized by having many ethnic minorities. Of the $8.22 \times 10^{5}$ ha total territory, $75.8 \%$ is mountainous and $15.2 \%$ is hilly, making the landscape into an undulating terrain with a variety of landforms. Cropland is mainly scattered on the slopes, with more dry land and less paddy land than provinces to the east and north. The population density is $340 \mathrm{~km}^{-2}$, about 2.6 times higher than the average for all of China. The cropland per capita is less than 0.09 ha or $76 \%$ of the national average. Without considering cropland abandonment by peasants, cropland area in Chongqing has decreased at a pace of $3.14 \times 10^{4}$ ha per year in the past 15 years as a result of the Grain for Green Program and the construction booming driven by urban expansion. In addition to the severe cropland scarcity, soil erosion has been a grave concern, with $49 \%$ of the entire agricultural areas of the municipality having different degrees of soil erosion. In southwestern and northwestern Chongqing, this figure increases to more than 70\% (Li et al., 2009).

With the strong support of the central government, Chongqing government has implemented a series of policies and measures to alleviate poverty, in tandem with ecosystem restoration. The leading policy in this effort is the reform of the household registration system, which aims to eliminate the historical socioeconomic gap between peasants in rural areas and citizens in the cities and towns (Lu et al., 2014). Under the reform scheme, rural and urban citizens are treated equality in terms of having the same identity registration requirements and enjoying the same social service system.

\footnotetext{
3 The publications we have reviewed are typically based on data at regional or village scales, few based on household survey and none based on land plots.
}

The local governments in urban areas have also made great efforts to provide affordable public rental apartments to those who have newly migrated to urban areas from the rural areas of the jurisdiction (Li et al., 2014a). These policies have speeded up the migration flows from rural to urban areas and would exert impact on cropland abandonment in Chongqing. The official data show that from 2008 to 2011, more than 3 million rural residents changed their identities to urban residents and moved into the cities and towns of the metropolitan areas.

Our survey focuses on Southwest Chongqing, which arguably has the most fragile ecosystem in Chongqing and is vulnerable to soil erosion. Eight administrative villages in two counties were selected for the survey. A two-stage process was adopted to select the administrative villages. First, Youyang County and Wulong County were selected as representative counties because these two counties are largely covered by mountainous landscapes, with ecosystems vulnerable to erosion and natural disaster damages, and having experienced high rates of rural-to-urban migration. Youyang County is located in $28^{\circ} 19^{\prime}-29^{\circ} 24^{\prime} \mathrm{N}$ and $108^{\circ} 18^{\prime}-109^{\circ} 19^{\prime} \mathrm{E}$, occupying 5173 square kilometers, and with forests covering about $31.7 \%$ of the county. Youyang had a registered population of 839,400 in 2011 , of which 265,300 had out-migrated according to 2011 population census criteria. Wulong county is located in $29^{\circ} 02^{\prime}-29^{\circ} 40^{\prime} \mathrm{N}$ and $107^{\circ} 13^{\prime}-108^{\circ} 05^{\prime} \mathrm{E}$, occupying 2901 square kilometers, and with forests covering about $36.3 \%$ of its territory. Wulong had a registered population of 413,000 in 2011, of which 6470 had out-migrated according to 2011 population census criteria. Second, four villages were purposefully selected in each county based on the following four criteria: (a) observable cropland abandonment, (b) typical mountain area with multiple landforms, (c) high level of rural-to-urban labor migration, (d) having diverse features in terms of per capita income level and biophysical heterogeneity indicators as listed in Table 1. Fig. 1 shows the location and visualized geographical features of the surveyed areas, including the locations of the eight villages.

Despite that the research team has rich survey experiences in rural China, we kept pre-cautious because it is also a land-plot based survey. Therefore, we ran a trial survey for one week in June 2012 to identify potential problems and questions which might be prone to misunderstanding. We follow the definition of cropland abandonment by the Ministry of Land and Resources of the People's Republic of China: Cropland abandonment means fallow for more than three sequential years. ${ }^{4}$ We trained six postgraduate students from Southwest University on household survey and group discussion during the trial survey. After the trial run, we revised and improved the questionnaire based on feedback from the trial survey. The full survey was run in July and August 2012 by us and the six postgraduate students.

During the full survey, we first conducted interviews and discussions with the leaders of each administrative village and natural village, including recognized community leaders. We asked their advice in stratifying their village households based on livelihood strategy of each household. The livelihood strategies of local households can be categorized into four types: pure farm household with agriculture income proportion between 90 and 100\%, mixed farm-business household (type I) with agriculture income proportion between 50 and 90\%, mixed farm-business household (type II) with off-farm income proportion between 51 and $90 \%$, and none farm household with off-farm income proportion more than $90 \%$. We then allocated expected number of surveyed households into each of these four stratified household groups based on the pro-

\footnotetext{
4 The study area is in subtropical zone. During the first 3-5 years, abandoned fields are mainly covered by grass, and then bushes. For about $10-15$ years, such fields will be covered by local trees.
} 
Table 1

General features of the eight surveyed villages in Chongqing.

\begin{tabular}{|c|c|c|c|c|c|c|c|c|}
\hline \multicolumn{3}{|l|}{ County } & \multicolumn{2}{|l|}{ Youyang } & \multirow[b]{2}{*}{ Eguan } & \multicolumn{3}{|l|}{ Wulong } \\
\hline Administrative village & Tiancang & Shuanglong & Li'er & Dabanying & & Qianjin & Dongsheng & Chepan \\
\hline Area $\left(\mathrm{km}^{2}\right)$ & 12.85 & 20.90 & 36.76 & 52.43 & 8.81 & 20.06 & 9.31 & 5.80 \\
\hline Household & 511 & 435 & 479 & 448 & 1225 & 471 & 290 & 495 \\
\hline Average elevation (m) & 1172.10 & 846.87 & 1047.39 & 672.63 & 292.12 & 824.26 & 1016.05 & 1285.64 \\
\hline Cropland p.c. (ha) & 0.18 & 0.10 & 0.12 & 0.19 & 0.09 & 0.08 & 0.12 & 0.09 \\
\hline$\%$ of cropland slope over $25^{\circ}$ & 10.50 & 36.30 & 34.23 & 62.44 & 3.85 & 27.69 & 12.11 & 36.42 \\
\hline Forest coverage (\%) & 64.14 & 50.77 & 70.15 & 83.84 & 33.95 & 78.4 & 55.87 & 79.93 \\
\hline Livestock type & Pig, Buffalo & Pig & $\begin{array}{l}\text { Pig, buffalo, } \\
\text { goat }\end{array}$ & $\begin{array}{l}\text { Pig, buffalo, } \\
\text { goat }\end{array}$ & Pig & Pig & Pig & Pig \\
\hline$\%$ of off-farm laborers & 58.54 & 72.80 & 61.13 & 70.78 & 36.43 & 15.45 & 30.81 & 53.07 \\
\hline Main crops & $\begin{array}{l}\text { Sweet potato, } \\
\text { maize, potato, } \\
\text { tobacco, } \\
\text { vegetable }\end{array}$ & $\begin{array}{l}\text { Maize, rice, } \\
\text { sweet potato, } \\
\text { potato, tobacco }\end{array}$ & $\begin{array}{l}\text { Maize, sweet } \\
\text { potato, potato, } \\
\text { tobacco }\end{array}$ & $\begin{array}{l}\text { Maize, sweet } \\
\text { potato, potato, } \\
\text { tobacco }\end{array}$ & $\begin{array}{l}\text { Rice, maize, } \\
\text { sweet potato, } \\
\text { potato, rape }\end{array}$ & $\begin{array}{l}\text { Rice, vegetable, } \\
\text { maize, tobacco, }\end{array}$ & $\begin{array}{l}\text { Rice, maize, } \\
\text { tobacco, rape }\end{array}$ & $\begin{array}{l}\text { Tobacco, maize, } \\
\text { rice, vegetable }\end{array}$ \\
\hline Infrastructure & $\begin{array}{l}\text { Near a town, } \\
\text { access to paved } \\
\text { road, poor } \\
\text { irrigation }\end{array}$ & $\begin{array}{l}4 \mathrm{~km} \text { to town, } \\
\text { gravel road, } \\
\text { poor irrigation }\end{array}$ & $\begin{array}{l}5 \mathrm{~km} \text { to town, } \\
\text { paved road }\end{array}$ & $\begin{array}{l}7 \mathrm{~km} \text { to town, } \\
\text { gravel road, } \\
\text { residents } \\
\text { scattered }\end{array}$ & $\begin{array}{l}\text { Near town, } \\
\text { paved road, } \\
\text { poor irrigation }\end{array}$ & $\begin{array}{l}14 \mathrm{~km} \text { to town, } \\
\text { paved road, } \\
\text { poor irrigation }\end{array}$ & $\begin{array}{l}13 \mathrm{~km} \text { to town, } \\
\text { paved road, } \\
\text { poor irrigation }\end{array}$ & $\begin{array}{l}30 \mathrm{~km} \text { to } \\
\text { township, } \\
\text { paved road }\end{array}$ \\
\hline Sampled household & 81 & 80 & 84 & 79 & 77 & 81 & 79 & 80 \\
\hline$\%$ of sampled in the total & 15.85 & 18.40 & 17.54 & 17.63 & 6.28 & 17.20 & 27.24 & 16.16 \\
\hline Valid questionnaires & 79 & 76 & 77 & $\begin{array}{l}56 \text { (19 farmers } \\
\text { excluded as } \\
\text { their } \\
\text { contracted land } \\
\text { area is more } \\
\text { than } 40 \mathrm{mu} \text { ) }\end{array}$ & 76 & 80 & 79 & 76 \\
\hline
\end{tabular}

Note: $1 \mathrm{mu}=1 / 15$ ha.

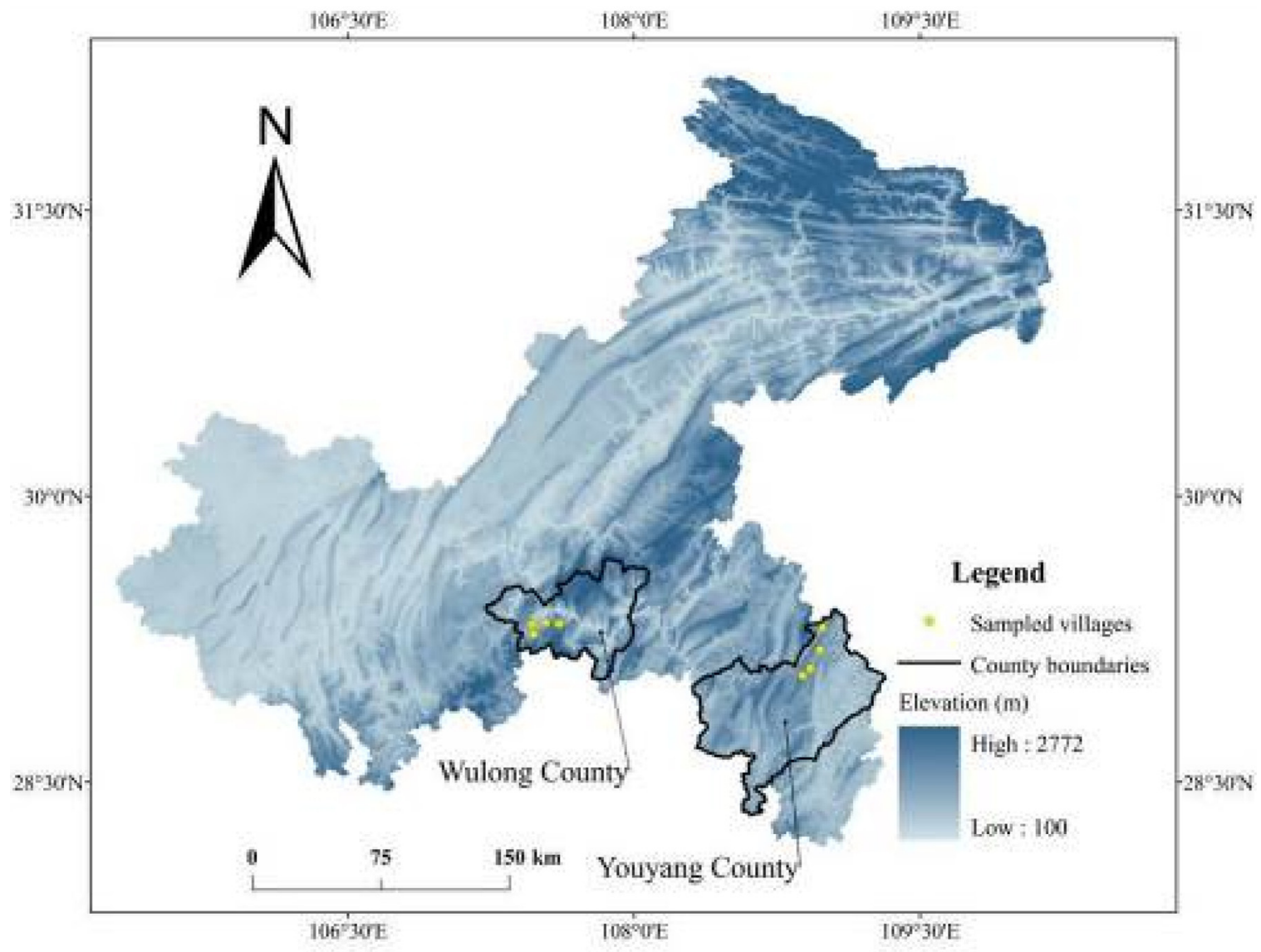

Fig. 1. Location of the study areas.

portion of each group in the total number of households of the administrative village, allowing minor variations to accommodating special cases. For example, if all family members of a chosen household had out-migrated, another household nearby can be chosen as a replacement. The face-to-face interview for completing the questionnaire was carried out in the house or yard of the sam- 
pled household, mainly with the household head, although other household members may step-in to provide supplemental information as needed. Each interview lasted for $2-3 \mathrm{~h}$. The major content of the questionnaire included: (1) Basic information of the household, such as household size, age structure, levels of education, status of off-farm employment, etc; (2) Land use and land conditions, including number of plots and plot-specific information on plot sizes, land type, official grade of land quality, distance to home, cropping types, and status of cropping or fallowing or abandoning, participating in Grain for Green Program and the associated subsidy received from the Program; (3) Income and expenditure structures of the household. When we finished field survey in every village, we asked the local leaders of each administrative village and natural village, including recognized community leaders, to review the questionnaires, in particular with regard to the questions on cropland abandonment, and to correct mistakes. To validate the accuracy of abandonment answers, we also run a validation by visiting randomly selected plots and checking the vegetation state of these plots. The validation test was highly satisfactory. In total, 80 households in each of the 8 villages were surveyed and 599 of the total 640 questionnaires were completed and passed validation test. The survey data cover 5258 plots of officially contracted cropland, with 2506 in Youyang and 2752 in Wulong. The data were processed and managed with SPSS 18.

Of the total 599 sample households, 378 have the record of one or more abandoned cropland plots. Of the total 5258 sample plots, 1348 have been abandoned, covering about 104.51 ha and accounting for $30.36 \%$ of all sample plots. These figures indicate that cropland abandonment is very common in the survey area. The reason may lies in that the surveyed regions are truly dominated by mountainous landscape, and furthermore our survey on every plot of a surveyed household also helps capture the full extent and dynamics of cropland abandonment phenomenon.

\section{The household decision model}

A sequence of three models is developed in this section. The first one is a baseline model that captures household decisions on farmland use when the labor market is perfect. The second model captures the reality that there is a transaction cost in entering off-farm employment. Thus, households with various labor components face different levels of ration in entering the off-farm labor market. The third model incorporates the heterogeneous distribution of soil/land quality.

\subsection{Basic setup}

The basic modeling setting first captures the key features of the land contracting system prevailing in China that each rural household has multiple contracted plots scattered in different locations, with different soil quality and geographic features. The modeling goal is to investigate the optimal decisions of rural households on agricultural land-use scale and intensity and labor allocation. The household maximizes the total revenue obtained from both agricultural and non-agricultural activities less the cost of production. The key decision variables are (a) the farming scale $A_{i}$ on plot $i$ and (b) agricultural labor input $l_{a i}$ on this plot. We assume that agricultural goods are identical in all plots for simplicity. In this setup, farmers do not have the right to choose plots and farmland expansion or shrinking is not taken into consideration. A plot $\bar{A}_{i}$ is defined as a continuous piece of land. The full size of a plot is denoted as

Fallow land is defined as a piece of land that are owned by a household but not fully cultivated. Thus, there are at least two lev- els of fallow: complete fallow $\left(A_{i}=0\right)$ and partial fallow $\left(0<A_{i}<\bar{A}_{i}\right)^{5}$ A piece of land is characterized by its soil property and geographic features. The soil quality variable $s_{i}$ is a parameter that represents soil quality (land fertility) of each plot. Thus, we assume homogeneity of soil quality of each plot. The reason of setting $s_{i}$ as a parameter is that farmers can only decide to give up farming on one plot rather than changing plots. Hence, farmers can only take soil quality as exogenous. In addition, each plot is described by a bunch of geographic features such as irrigation condition, distance between the plot and residence of the household which has contracted use-right on the plot, land quality grade, elevation, etc. We introduce a vector $d_{i}$ to represent all perspectives of geographic conditions. The influence of these geographic features on agricultural production can be positive, negative, or neutral.

Agricultural production function is defined at the plot level and is specified in a standard form: $f\left(A_{i}, l_{a i}, s_{i}\right)$ is increasing and concave in labor $l_{a i}$ and farming scale $A_{i}$. We further assume that $f\left(A_{i}, l_{a i}, s_{i}\right)$ is a super modular in $l_{a i}$ and $A_{i}$ (i.e., $f_{A l_{a}}>0$ ). The productivity of each plot is also associated with its soil quality, as soil quality is widely defined as the behavior of soil in crop growth. We assume that plots with better soil quality are more productive because the marginal productivity of labor and scale effect are greater (i.e., $f_{A_{i} s_{i}}>0$ and $f_{l_{a i} s_{i}}>0$ ).

The cost of agricultural production, $C\left(A_{i}, l_{a i}, s_{i}\right)$, is assumed to be convex and increasing in $A$. Because a higher level of soil quality decreases production cost, $C_{A_{i} s_{i}}<0$. Positive geographic features decrease the marginal cost of scale, implying $C_{A_{i} d_{i}}<0$; on the other hand, negative geographic features increase the marginal cost of scale, indicating $C_{A_{i} d_{i}}>0 ; C_{A_{i} d_{i}}=0$ if $d_{i}$ has no impacts on agricultural production. The cost of labor is measured by the market value, which is the wage rate $(w)$ in non-agricultural sector if that market is perfect.

\subsection{The baseline model with a perfect labor market}

With a perfect labor market, the production decision of a household is separable from its utility maximization decision as consumers when the marginal utility of leisure is equal to the offfarm wage rate $w$ and the marginal utility of a unit of consumption good is 1 (Benjamin, 1992). The producer's objective function of the household with $N$ plots is as follows.

$\max _{A_{i} l_{a i}} \sum_{i=1}^{N} f\left(A_{i}, l_{a i}, s_{i}\right)-\sum_{i=1}^{N} C\left(A_{i}, l_{a i}, s_{i}\right)+w\left(L-\sum_{i=1}^{N} l_{a i}\right)$,

in which $p$ is the selling price of the agricultural product and $L$ is the total labor supply of the household. This objective function indicates that the household maximizes the aggregate revenue of agricultural production of $N$ plots less the aggregate cost. The constraints the producer faces include a) the subsistence constraint $F$ of the household, meaning that agricultural production should be no less than the subsistence constraint; b) the area under farming on a plot cannot be greater than its initial endowment $\bar{A}_{i}$; c) on-farm labor cannot be less than zero. These constraints can be formulated as follows.

$f\left(A_{i}, l_{a i}, s_{i}\right) \geq F$

$A_{i} \leq \bar{A}_{i}$

$l_{a i} \geq 0$

\footnotetext{
5 To make a link to the terminologies in the empirical part, "complete fallow" means abandonment, and "partial fallow" means extensive land use or fallow for one year or less.
} 
The Lagrangian function is:

$$
\begin{aligned}
& p \sum_{i=1}^{N} f\left(A_{i}, l_{a i}, s_{i}\right)-\sum_{i=1}^{N} C\left(A_{i}, l_{a i}, s_{i}\right)+w\left(L-\sum_{i=1}^{N} l_{a i}\right) \\
& \quad+\kappa\left(\sum_{i=1}^{N} f\left(A_{i}, l_{a i}, s_{i}\right)-F\right)-\sum_{i=1}^{N} \mu_{i}\left(A_{i}-\bar{A}_{i}\right)+\sum_{i=1}^{N} \lambda_{i} l_{a i} .
\end{aligned}
$$

The first order conditions are

$p f_{A_{i}}-C_{A_{i}}+\kappa f_{A_{i}}-\mu_{i}=0$,

$p f_{l_{a i}}-C_{l_{a i}}-w+\kappa f_{l_{a i}}+\lambda_{i}=0$.

Based on (1) and (2), three cases can be distinguished.

Case 1. The plots that is fully cultivated

The first order conditions are rewritten as

$p f_{A_{i}}-C_{A_{i}}+\kappa f_{A_{i}}-\mu_{i}=0$

$p f_{l_{a i}}-C_{l_{a i}}-w+\kappa f_{l_{a i}}=0$.

The first equation shows that it is optimal to cultivate the entire plot when the marginal benefit at the scale of $A_{i}^{*}=\bar{A}_{i}$ is greater than the marginal cost at this scale adjusted by the subsistence constraint. The second equation shows that it is optimal to allocate labor to this plot when the marginal (net) benefit of labor input is greater than the marginal cost $w$ adjusted by the subsistence constraint.

Case 2. The plot that is partially fallow

The first order conditions are rewritten as

$p f_{A_{i}}-C_{A_{i}}+\kappa f_{A_{i}}=0$,

$p f_{l_{a i}}-C_{l_{a i}}-w+\kappa f_{l_{a i}}=0$.

This is the case when the marginal benefit at the scale of $A_{i}^{*}<\bar{A}_{i}$ is equal to the marginal cost of farming at this scale and when the (net) marginal benefit of labor input is also equal to its marginal cost, adjusted by subsistence constraint as in Case 1 . In this case, farmers still have incentives to allocate labor to this plot. However, the farming scale is less than the full scale because the plot is only utilized at the point when the marginal benefit is not less than the marginal cost.

Case 3. The plot that is completely fallow

The first order conditions are rewritten as

$p f_{A_{i}}-C_{A_{i}}+\kappa f_{A_{i}}=0$,

$p f_{l_{a i}}-C_{l_{a i}}-w+\kappa f_{l_{a i}}+\lambda_{i}=0$.

This is the case when the (net) marginal benefit of labor input is less than the marginal cost adjusted by the subsistent constraint. Thus, farmers would give up this plot because it is not economically rational to allocate any labor onto this plot.

The second order condition matrix for the decision variables has the following feature:

$\left[\begin{array}{ll}- & + \\ + & -\end{array}\right]$.

Because the assumptions we made satisfy the second order conditions. The determinant of this second order condition matrix is positive. The matrix for the parameter $s_{i}$ has the feature:

$\left[\begin{array}{l}+ \\ +\end{array}\right]$
Thus, we have $\frac{\partial A_{i}}{\partial s_{i}}>0$ and $\frac{\partial l_{a i}}{\partial s_{i}}>0$. These results show that a plot with higher soil quality (land fertility) is less likely to be partially or completely abandoned. Using the same method, it can be shown that the geographical variables with different properties have different impacts on farmers' decisions. For example, features exerting negative influence on farming such as a longer distance between the plot and the household's residence $\left(\frac{\partial A_{i}}{\partial d_{i}}<0\right.$ and $\frac{\partial l_{a i}}{\partial d_{i}}<0$ ) would make the plot more likely to be abandoned. In contrast, features positively influencing farming activities such as good irrigation condition would make the plot less likely to be abandoned.

\subsection{Imperfect labor market}

In an imperfect labor market, each rural household face a different transaction cost in entering the labor market. The transaction cost comes from the facts that rural labor is often isolated and discriminated by the urban social services system (Cai et al., 2008; Solinger, 1999). Thus, relatively aged rural laborers would not be able to fully participate in the urban labor market. In this section, we discuss how decisions of farming are distorted by the ration of labor market. We introduce a constraint on off-farm labor. Off-farm labor supply is not greater than $\psi_{h} L$, where $\psi_{h}$ captures the proportion of young labor of household $h$, who are more likely to obtain off-farm employment. Each family has a different $\psi_{h}$ due to different demographic structure. With an imperfect labor market, there is no separation between producer's profit maximization problem and consumers' utility maximization problem for the household concerned. Thus, the decisions on farming scale and labor allocation rely on the optimal solutions of the utility maximization problem (Benjamin, 1992). Each household maximizes the utility from leisure $l$ and consumption $c$.

$\max _{A_{i}, l_{a i}, l_{k}, c} U(c, l)$,

$c=p \sum_{i=1}^{N} f\left(A_{i}, l_{a i}, s_{i}\right)-\sum_{i=1}^{N} C\left(A_{i}, l_{a i}, s_{i}\right)+w\left(L-\sum_{i=1}^{N} l_{a i}-l\right)$,

$f\left(A_{i}, l_{a i}, s_{i}\right) \geq F$,

$A_{i} \leq \bar{A}_{i}$

$l_{a i} \geq 0$,

$\sum_{i=1}^{N} l_{a i}+l_{k}+l=L$

$L-\sum_{i=1}^{N} l_{a i}-l \leq \psi L$

Let $\theta$ stand for the co-state variable of the off-farm labor supply constraint in the Lagrangian function, the first order conditions are:

$U_{c}\left(p f_{A_{i}}-C_{A_{i}}\right)+\kappa f_{A_{i}}-\mu_{i}=0$,

$U_{c}\left(p f_{l_{a i}}-C_{l_{a i}}-w\right)+\kappa f_{l_{a i}}+\lambda_{i}+\theta=0$,

$U_{c}(-w)+U_{l}+\lambda_{i}+\theta=0$.

Comparing Eqs. (3)-(4) and Eqs. (1)-(2), it is clear that when the off-farm labor constraint is binding (i.e., $\theta \neq 0$ ), based on the assumptions of concavity and positive cross derivatives, farming 
labor supply and farming size on each plot under the condition of an imperfect labor market are greater than those under the condition of a perfect labor market. Intuitively speaking, because labor cannot be effectively moved to the off-farm labor market, farmers oversupply labor and land on farming compared with the decisions under the condition of a perfect labor market. Thus, a plot that is fallowed (or partial fallowed) with a perfect labor market is utilized when the labor market is not perfect. This is consistent with conclusions in Benjamin (1992) that off-farm labor constraint leads to over investment in agriculture when there is no separability. Meanwhile, Eq. (5) show that the marginal utility of leisure $\left(U_{l}\right)$ is less than the marginal cost of leisure $w U_{c}$, which is the marginal utility gained if this additional time is used for making consumption goods. This further demonstrates that farmers take less leisure compared with the baseline model to support agriculture production when the off-farm constraint is binding. Thus, households with more severe off-farm constraint would abandon fewer plots than those with less severe constraint. It is also important to discuss the horizontal comparison of plots. Because of the positive $\theta$ with an imperfect labor market, plots that are completely fallowed in the baseline model (Case 3) due to low soil quality and negative geographic features are less likely to be abandoned. This is owing to the fact that even through it is not worth allocating any labor on this plot, labor cannot be transferred to the off-farm labor market and it is not the optimal to increase leisure, labor has to be allocate back to farming activities.

\subsection{Considering soil quality distribution}

Now let's investigate the effect of different soil quality (land fertility) on farming decision. For a focused discussion, we assume that there are two types of soil quality in general: high type and low type; and we further assume that there is no scale difference among plots that are grouped into one type of soil quality. We assume that there are $M$ plots with high soil quality and $N$ plots with low soil quality. Thus, the maximization problem is rewritten as:

$$
\begin{aligned}
& \max _{A_{i}^{H}, A_{j}^{L}, l_{a i}^{H},{ }_{a j}^{L}} p M f\left(A_{i}^{H}, l_{a i}^{H}, s^{H}\right)-M C\left(A_{i}^{H}, s^{H}, d_{H}\right)+p N f\left(A_{j}^{L}, l_{a j}^{L}, s^{L}\right) \\
& \quad-N C\left(A_{j}^{L}, s^{L}, d_{L}\right)+w\left(L-\sum_{i=1}^{M+N} l_{a i}\right),
\end{aligned}
$$

subject to

$\operatorname{Mf}\left(A_{i}^{H}, l_{a i}^{H}, s^{H}\right)+N f\left(A_{j}^{L}, l_{a j}^{L}, s^{L}\right) \geq F$,

$A_{i}^{H} \leq \bar{A}_{i}, \quad A_{j}^{L} \leq \bar{A}_{j}$

$l_{a i}^{H} \geq 0, \quad l_{a j}^{L} \geq 0$.

The first order conditions are

$$
\begin{aligned}
& p M f_{A_{i}^{H}}-M C_{A_{i}^{H}}+\kappa M f_{A_{i}^{H}}-\mu_{i}^{H}=0, \\
& p N f_{A_{j}^{L}}-N C_{A_{j}^{L}}+\kappa N f_{A_{j}^{L}}-\mu_{j}^{L}=0, \\
& p M f_{l_{a i}^{H}}-M C_{l_{a i}^{H}}-w+\kappa M f_{l_{a i}^{H}}-\mu_{i}^{H}=0, \\
& p N f_{l_{a j}^{L}}-N C_{l_{a j}^{L}}-w+\kappa N f_{l_{a j}^{L}}-\mu_{j}^{L}=0 .
\end{aligned}
$$

We assume that the marginal cost of production in all high quality plots are lower than that in low quality plots at the same level of geographic conditions, and the marginal productivity is always higher in the high quality land. Thus, it is easy to see that it is impossible to have a situation where farmers only cultivate the low soil quality land if they do have high soil quality plots with a same level of geographic conditions. It is because if $\mu^{H}>0, \mu^{L}$ cannot be zero. Thus, farmers with more high quality plots are less likely to abandon agricultural activities on these plots if it is optimal to allocate labor on farming. Intuitively, farmers gradually give up farming from the lowest productivity plots with the lowest soil quality.

\section{Econometric model and the estimation results}

The above theoretical model directly leads to a logit model shown in Eq. (10):

$\operatorname{Pr}\left(Y_{i}=1 \mid X_{i}\right)=\frac{\exp \left(\alpha+X_{i} \beta\right)}{1+\exp \left(\alpha+X_{i} \beta\right)}$.

In Eq. (10), the dependent variable $Y_{i}$ takes value of 0 or $1 . Y_{i}=1$ means that plot $i$ is abandoned and $Y_{i}=0$ means that plot $i$ is cultivated. The vector of independent variables $\left(X_{i}\right)$ includes two sets of variables, one corresponding to the household which has the contracted control right over plot $i$, and the other corresponding to the features of plot $i$ itself. The major household variables include the average wage income of family members who have employment in non-agricultural sectors, agricultural income from on-farm activities of the household, population size of the household, total number of land plots contracted to the household, and average cultivated farmland area per laborer within the household. We also include the education level and age of the household head, and the distance between the residence of the household to the closest town as household-level control variables. The plot specific variables include plot size, irrigation condition, the distance between the plot and the residence of the household, land quality grade, likelihood to crop damages caused by wild boars and other wild animals. Our survey data show that 410 of the 599 households with valid questionnaires earned regular wage income from non-agricultural sectors; of the 189 households without regular wage income, 50 had family members engaging in non-agricultural work for less than 3 months per year. This clearly indicates that non-agricultural activities have become an important source of household income in the surveyed households. Table 2 presents the definition of these variables and the summary statistics. Table 3 reports the correlation coefficients between explanatory variables and it shows that the absolute values of these coefficients are all smaller than 0.5 , with the only exception of that between "elevation" and "distance to town" $(r=0.734)$.

We estimate Eq. (10) using both the Probit and Logit models and apply the Huber-White sandwich estimator to control for the clustered data structure and potential spatial autocorrelation caused by multiple samples within the same village (Prishchepov et al., 2013). This control is necessary because villages are the grass-root administrative units in China with constitutionally granted rights on self-governance and self-regulating (Pesqué-Cela et al., 2009). This means that households in the same village follow the same set of self-regulating rules in land contracting and land-use decisions. This feature would lead to clustered data structure and potential spatial autocorrelation for those sample households from the same village.

Except for education, damage caused by wild animals, land grade, and irrigation, we take the logarithms of all other variables. With regard to wage income, if it is zero, we take $\ln$ (wage income $)=0$. Because the minimum value of wage income next to zero is 1800 yuan, such a simplification does not distort the estimation.

We use Stata to run the regressions. We employ the receiver operating characteristic curve (ROC) to assess the overall performance of the model in terms of the goodness-of-fit. The value of ROC, which is defined as the area under this curve, varies between 0.5 (completely random) and 1 (perfect discrimination). Fig. 2 
Table 2

The definition of variables, summary statistics, and the expected effects of variables.

\begin{tabular}{|c|c|c|c|c|c|c|}
\hline Variables & Description & Minimum & Maximum & Mean & $\begin{array}{l}\text { Standard } \\
\text { Deviation }\end{array}$ & $\begin{array}{l}\text { Expected } \\
\text { effect }\end{array}$ \\
\hline \multicolumn{7}{|l|}{ Dependent variable } \\
\hline Abandonment & $\begin{array}{l}\text { If a plot was not cultivated for more than } 3 \text { sequential } \\
\text { years, the variable takes } 1 \text { on this plot, otherwise } 0 \text {. }\end{array}$ & & & 0.256 & 0.437 & \\
\hline \multicolumn{7}{|l|}{ Independent Variables } \\
\hline Wage income $(\ln )$ & $\begin{array}{l}\text { Average annual wage income of family member who } \\
\text { engaged in non-agricultural work for more than } 3 \\
\text { months (yuan). }\end{array}$ & 0.000 & 11.695 & 7.092 & 4.631 & + \\
\hline Agricultural income (ln) & Income from cropping and livestock (yuan). & 0.000 & 11.741 & 8.708 & 1.229 & - \\
\hline Number of plots (ln) & The number of plots contracted to the household. & 0.000 & 3.219 & 2.354 & 0.455 & + \\
\hline Cultivated land area per laborer (ln) & $\begin{array}{l}\text { Total cultivated land area/no of laborers in the } \\
\text { household ( } \mathrm{mu}) \text {. }\end{array}$ & -3.912 & 3.091 & 0.912 & 0.781 & + \\
\hline Household size (ln) & Number of household members. & 0.000 & 2.197 & 1.335 & 0.443 & - \\
\hline Distance to town (ln) & The distance from the house to the nearest town $(\mathrm{km})$. & 0.000 & 3.970 & 2.065 & 0.786 & - \\
\hline Age $(\ln )$ & Age of household head. & 3.401 & 4.454 & 3.997 & 0.215 & $+1-$ \\
\hline Education & $\begin{array}{l}\text { Dummy variable for household head: } 1 \text { for illiterate, } 2 \\
\text { for primary school, } 3 \text { for middle school, } 4 \text { for high } \\
\text { school, } 5 \text { for college and above. }\end{array}$ & 1.000 & 5.000 & 2.193 & 0.742 & $+1-$ \\
\hline Plot-home distance (ln) & $\begin{array}{l}\text { Distance between the plot and the home of the } \\
\text { household }(\mathrm{km})\end{array}$ & -6.908 & 2.485 & -0.866 & 1.219 & + \\
\hline Plot size $(\ln )$ & Area of each plot (mu) & -4.423 & 2.708 & -0.524 & 1.014 & - \\
\hline Land grade & $\begin{array}{l}\text { Dummy variable for land grade in the land contract } \\
\text { book: } 1 \text { for first grade, } 2 \text { for second grade, } 3 \text { for third } \\
\text { grade, } 4 \text { for fourth grade, } 5 \text { for the others. The higher } \\
\text { degree of land grade means lower land quality. }\end{array}$ & 1.000 & 5.000 & 2.495 & 0.898 & + \\
\hline Irrigation & $\begin{array}{l}\text { Dummy variable for Irrigation: } 1 \text { for the plot can be } \\
\text { irrigated, } 0 \text { for only rain-fed plots. }\end{array}$ & 0.000 & 1.000 & 0.136 & 0.343 & - \\
\hline Wild animal attack & $\begin{array}{l}\text { Human-wildlife conflict, mainly wild boar, is severe in } \\
\text { the study area. Dummy variable: } 1 \text { for the plot suffered } \\
\text { from wild-animals' attack, } 0 \text { for did not suffer. }\end{array}$ & 0.000 & 1.000 & 0.213 & 0.450 & + \\
\hline Elevation (ln) & Elevation of the house by GPS (100m) & 1.001 & 2.942 & 2.116 & 0.365 & + \\
\hline
\end{tabular}

Table 3

The correlation between explanatory variables.

\begin{tabular}{|c|c|c|c|c|c|c|c|c|c|c|c|c|c|}
\hline & Wage (ln) & $\begin{array}{l}\text { Agri. } \\
\text { income } \\
(\ln )\end{array}$ & $\begin{array}{l}\text { No of } \\
\text { plots }(\ln )\end{array}$ & $\begin{array}{l}\text { Farmland } \\
\text { per } \\
\text { laborer } \\
(\ln )\end{array}$ & $\begin{array}{l}\text { Household } \\
\text { size }(\ln )\end{array}$ & $\begin{array}{l}\text { Distance } \\
\text { to town } \\
(\ln )\end{array}$ & Age (ln) & Education & $\begin{array}{l}\text { Plot- } \\
\text { home } \\
\text { distance } \\
\text { (ln) }\end{array}$ & $\begin{array}{l}\text { Plot area } \\
(\ln )\end{array}$ & $\begin{array}{l}\text { Land } \\
\text { grade }\end{array}$ & Irrigation & $\begin{array}{l}\text { Damage } \\
\text { by wild } \\
\text { animals }\end{array}$ \\
\hline $\begin{array}{l}\text { Agri. income } \\
\quad(\ln )\end{array}$ & -0.129 & & & & & & & & & & & & \\
\hline No of plots (ln) & 0.092 & 0.127 & & & & & & & & & & & \\
\hline $\begin{array}{l}\text { Farmland area } \\
\text { per laborer } \\
\text { (ln) }\end{array}$ & -0.318 & 0.001 & 0.270 & & & & & & & & & & \\
\hline $\begin{array}{l}\text { Household size } \\
\quad(\ln )\end{array}$ & 0.489 & 0.146 & 0.088 & -0.243 & & & & & & & & & \\
\hline $\begin{array}{l}\text { Distance to } \\
\text { town }(\ln )\end{array}$ & -0.169 & 0.024 & -0.009 & 0.179 & -0.094 & & & & & & & & \\
\hline Age $(\ln )$ & 0.017 & 0.048 & 0.069 & 0.030 & -0.086 & -0.058 & & & & & & & \\
\hline Education & 0.071 & 0.053 & 0.118 & -0.005 & 0.101 & 0.024 & -0.349 & & & & & & \\
\hline $\begin{array}{l}\text { Plot-home } \\
\text { distant (ln) }\end{array}$ & -0.019 & -0.080 & 0.094 & 0.126 & -0.003 & 0.055 & 0.009 & 0.001 & & & & & \\
\hline Plot area $(\ln )$ & -0.060 & 0.010 & -0.218 & 0.387 & 0.056 & 0.109 & 0.057 & -0.049 & 0.093 & & & & \\
\hline Land grade & 0.002 & -0.018 & 0.017 & 0.043 & -0.012 & 0.167 & -0.033 & -0.018 & 0.228 & 0.015 & & & \\
\hline Irrigation & -0.001 & 0.069 & 0.005 & -0.071 & 0.016 & -0.144 & -0.015 & 0.014 & -0.158 & -0.069 & -0.208 & & \\
\hline $\begin{array}{l}\text { Damage by } \\
\text { wild animals }\end{array}$ & 0.022 & -0.192 & 0.049 & 0.157 & -0.041 & 0.093 & 0.055 & -0.051 & 0.316 & 0.115 & 0.161 & -0.137 & \\
\hline Elevation (ln) & -0.183 & -0.024 & -0.022 & 0.284 & -0.119 & 0.734 & -0.015 & 0.013 & 0.078 & 0.225 & 0.132 & -0.183 & 0.146 \\
\hline
\end{tabular}

presents the ROC for our Logit regression and the area under the curve is 0.902 , meaning that the model can distinguish correctly between two classes (stable managed agricultural land and abandoned agricultural land) with a probability of $90 \%$. This result is substantially better than the probability of separating these two classes solely by chance (DeLeo, 1993). Table 4 reports the results of both Probit and Logit regressions and shows that the both sets of results are statistically consistent in terms of signs and significance of individual coefficients across these two regressions. Of the 14 variables included in the two regressions, 9 are statistically signifi- cant, and Logit results show a higher significant level for Household size and Distance to town variables.

Among household variables, the estimated coefficients for wage income in two models are positive and statistically significant at the $5 \%$ level, which confirms our expectation that an increase in off-farm wage income would promote labor out-migration from the agricultural activities, and consequently leading to an increased probability of cropland abandonment. As presented earlier, 68\% of surveyed households are engaged in regular non-agricultural activities and off-farm income is their most important income, especially in terms of cash income. Because agricultural activities produce lit- 
Table 4

The regression results.

\begin{tabular}{|c|c|c|c|c|c|c|}
\hline \multirow[t]{2}{*}{ Variable } & \multicolumn{3}{|l|}{ Probit } & \multicolumn{3}{|l|}{ Logit } \\
\hline & Coefficient & Robust Standard error & $\mathrm{z}$ & Coefficient (Odds ratios) & Robust Standard error & $\mathrm{z}$ \\
\hline Wage income (ln) & $0.020^{* *}$ & 0.010 & 2.08 & $0.040^{* *}(1.041)$ & 0.019 & 2.18 \\
\hline Agri. income (ln) & $-0.206^{* * *}$ & 0.051 & -4.02 & $-0.366^{* * *}(0.694)$ & 0.094 & -3.89 \\
\hline No of plots (ln) & 0.154 & 0.156 & 0.98 & $0.288(1.334)$ & 0.275 & 1.05 \\
\hline Farmland area per laborer $(\ln )$ & $0.195^{*}$ & 0.113 & 1.73 & $0.360 *(1.433)$ & 0.209 & 1.72 \\
\hline Household size $(\ln )$ & $-0.163^{* *}$ & 0.073 & -2.22 & $-0.344^{* * *}(0.709)$ & 0.121 & -2.83 \\
\hline Distance to town $(\ln )$ & $-0.265^{*}$ & 0.146 & -1.81 & $-0.490^{* *}(0.612)$ & 0.266 & -1.84 \\
\hline Age $(\ln )$ & 0.231 & 0.186 & 1.25 & $0.474(1.607)$ & 0.349 & 1.36 \\
\hline Education & 0.004 & 0.046 & 0.08 & $0.017(1.017)$ & 0.092 & 0.18 \\
\hline Plot-home distance (ln) & $0.490^{* * *}$ & 0.049 & 10.03 & $0.938^{* * *}(2.554)$ & 0.090 & 10.47 \\
\hline Plot area $(\ln )$ & $-0.098^{* *}$ & 0.044 & -2.24 & $-0.173^{* *}(0.841)$ & 0.079 & -2.18 \\
\hline Land grade & $0.129^{* * *}$ & 0.020 & 6.31 & $0.226^{* * *}(1.253)$ & 0.036 & 6.26 \\
\hline Irrigation & -0.147 & 0.096 & -1.53 & $-0.286(0.751)$ & 0.172 & -1.66 \\
\hline Damage by wild animals & $1.588^{* * *}$ & 0.174 & 9.12 & $2.712^{* * *}(15.065)$ & 0.303 & 8.94 \\
\hline Elevation $(\ln )$ & 0.696 & 0.412 & 1.69 & $1.265(3.543)$ & 0.789 & 1.60 \\
\hline Intercept & $-1.778^{*}$ & 0.966 & -1.84 & $-3.387^{*}(0.034)$ & 1.847 & -1.83 \\
\hline No of observations & 5258 & & & 5258 & & \\
\hline Log pseudolikelihood & -1727.59 & & & -1721.58 & & \\
\hline Pseudo $\mathrm{R}^{2}$ & 0.423 & & & 0.425 & & \\
\hline Correctly classified & $86.76 \%$ & & & $86.86 \%$ & & \\
\hline Area under ROC & 0.902 & & & 0.902 & & \\
\hline
\end{tabular}

Notes: ${ }^{* * *},{ }^{* *}$ and $*$ represent the significance level at $1 \%, 5 \%$ and $10 \%$, respectively; () is Odds ratios.

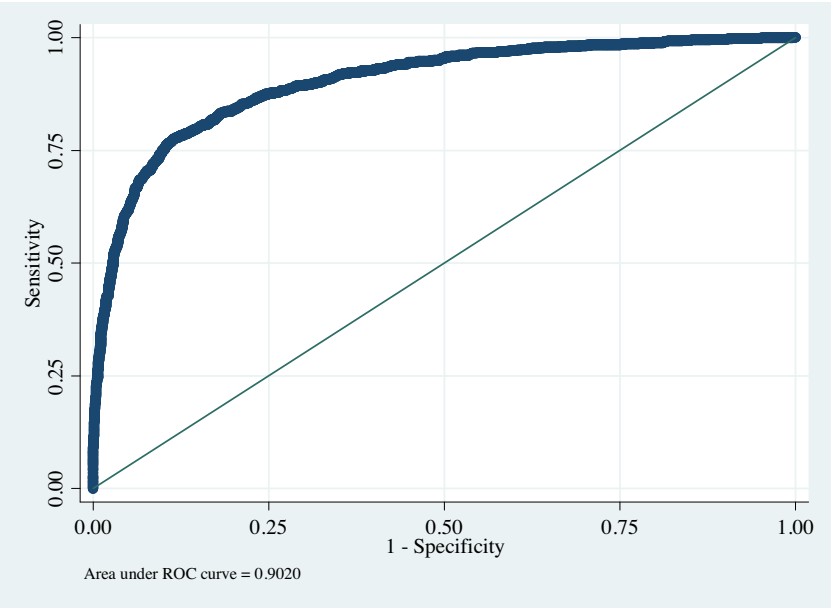

Fig. 2. The ROC test result of logit regression model.

tle cash income, an increase in off-farm wages will attract young agricultural laborers to move away from agricultural activities, leaving the elderly and children at home. This would cause a labor shortage in the traditional farming sector and increase the probability of cropland abandonment.

The variable agricultural income has a negative effect on cropland abandonment and the estimated coefficients are statistically significant at the $1 \%$ level. As indicated in the theoretical model, a household with higher agricultural income means the household remains to have a comparative advantage in farming. For example, such households may be specialized in growing high-valued cash crops such as vegetables, tobacco and herbs, as we saw during our fieldwork in several villages in Youyang and Wulong. Even for those growing grains and other traditional crops in a traditional way, the marginal benefits of farming is still higher than marginal cost of farming if taking subsistent consumption constraint into consideration. Intuitively speaking, the shadow wage rates from grain production might not be high, but still higher than the expected wage rate in non-agricultural employment, because as we discussed in Section 3.3, transaction cost for an aged and poorly educated farmer to find an off-farm job is high and the chance is small.
Although our expectation is that a household with more plots has higher abandonment probability, the result is not statistically significant. A plausible explanation is that more plots, due to diversified soil and climatic conditions in mountainous areas, can benefits the peasants in terms of risk diversification via diversified agricultural planting and more effective utilization of labor in association with the diversification strategy. This diversification strategy would finally lead to a higher net agricultural income. Similar observation is also reported in Ghana and Rwanda (Blare et al., 1992).

The coefficients on cultivated land area per laborer are positive and significant at the $10 \%$ level. A higher figure on cultivated land area per laborer may indicate more fragmented plots and higher demand for total manpower input because agriculture in this mountainous area still relies on the manpower and cattlepower. Therefore, the probability of land abandonment increases if a household has more cropland per laborer.

The estimated coefficients for household size are negative and statistically significant at the 5\% (Probit) and 1\% (Logit) levels respectively, suggesting that other things being equal, if a household has a larger supply of hands to agriculture and other activities, then the probability of cropland abandonment is lower.

Among household level control variables, distance to town shows a significant and negative relationship with cropland abandonment, which suggests a household located far away from town may have fewer opportunities of off-farm employment and will be more reliant on agricultural income, thus the possibility of cropland abandonment is lower. This finding is consistent with that of Baumann et al. (2011).

Although our expectation is that a household head with a higher level of education would have higher chance to find off-farm employment, and thus more education increases the probability of farmland abandonment (Schneider and Geoghegan, 2006). However, the results show that the level of education of the household head is not statistically significant. A plausible explanation might be that a household head receiving more education may be more capable of obtaining information and knowledge related to managing farming activities. For example, they may be able to operate a mini-tiller as a substitute for manual labor, and to better manage the applications of fertilizer, pesticides and other agricultural supplies. The combined effect of these two opposite reasoning makes the coefficient of education variable insignificant. For the 
age variable, two opposite effects exist as well and combined force of them makes the coefficient on age insignificant. On one hand, aging reduces the chance to find off-farm work and thus increasing labor availability for farming. On the other hand, aging means weaker physical condition and thus decreasing ability for farming, especially, for cultivating plots in faraway places.

Among plot-specific variables, the coefficients on plot size is negative and statistically significant at the 5\% level. Plot size affects the degree of mechanization, labor demand and management efficiency. For a larger plot, it is more cost-effective to use machines rather than manual labor, leading to a lower probability of cropland abandonment. This result confirms the rationale of policy efforts to promote land consolidation and to enlarge plot area.

As expected, coefficients on distance between the plot and home and land grade are positive and statistically significant at the $1 \%$ level. A plot located far away from the home of its entitled users is time-consuming and costly to access and manage and therefore is more likely to be abandoned. In fact, our survey data show that the proportion of abandoned plots increases with the distance from $10.06 \%$ at $0.4 \mathrm{~km}$ to $75.86 \%$ at $3 \mathrm{~km}$, and the proportion of abandoned area increases with the distance from $12.08 \%$ at $0.4 \mathrm{~km}$ to $83.22 \%$ at $3 \mathrm{~km}$. This finding is also consistent with that of Zhang et al. (2011) and Zhang et al. (2014).

Our expectation is that better irrigation condition is good for agricultural production, thus the abandonment probability is lower, but the result is not statistically significant. In the study area, $90 \%$ of the arable land is rain-fed. This unbalanced distribution may lead to the insignificant result.

In line with our expectation, the coefficients on Damage by wildanimals are positive and statistically significant at the $1 \%$ level. Wild animals, mainly wild boars, reproduce rapidly in the surveyed area partly owing to a series of forest protection and wildlife conservation policies. They have caused crop loss or even resulted in complete loss of harvest. From 2008 to 2010 , nearly $30 \%$ of the farming area of Chongqing has been severely damaged by wild boars. Farmers have taken many measures to deal with wild boars such as watchman guarding the areas, using firecrackers and bonfire, etc. Manpowered guarding during the harvest seasons is a popular means in the effort to protect crops. However, costs of guarding and protection can be too high for most of farmers in the surveyed areas. A reduced supply of agricultural laborers further increases the opportunity costs of such labor-intensive guarding and protection. As a consequence, a plot prone to attack by wild animals is more likely to be abandoned.

\section{Discussions and conclusion}

In this paper we have developed a rigorous theoretical model to formalize household decisions on farming scale when off-farm labor market is accessible and there is heterogeneity of farmland productivity and distribution. The model explains the hidden reasons of land abandonments in sloping and agriculturally lessfavored locations. To test theoretical predictions of the model, we apply the Probit and Logit estimators to a unique household and land-plot survey dataset of 5258 plots and 599 rural households in Chongqing, southwestern China. The survey shows that more than $30 \%$ of the sample plots have been abandoned since 1992 . The results of the econometric estimations confirm our theoretical expectations.

In comparison with the works of Zhang et al. (2014) and Li et al. (2014b), where off-farm wage income does not play a role or plays an insignificant and contradictory role, our results highlight the importance of off-farm wage income in determining the probability of cropland abandonment. The estimated coefficients on wage income in both Probit and Logit models have the expected positive sign and are statistically significant at the 5\% level. This confirms that an increase in off-farm wage income would lead to an increased probability of cropland abandonment. The intuition is as follows: An increase in off-farm wages will attract young people in the village to move away from agricultural activities, leaving the elderly to look after farmland. The resultant labor shortage in the traditional farming sector leads to an increase in the probability of cropland abandonment.

The major forces driving cropland abandonment we have revealed in this case study is similar to those in Western Europe, where cropland abandonment was resulted from longterm socio-economic transformation such as urbanization and industrialization. One highlight in this paper is the overriding importance of the rising off-farm wage rate of an average peasant, which have increased at a double-digit rate during last 10 years. On the other hand, our case is different from that of the postsocialist countries in Eastern Europe, where cropland abandonment is largely a result of the institutional and economic shock.

The rural depopulation because of out-migration at a large scale has been regarded as the top driver of cropland abandonment in many countries. However, it is not the case in our research areas. It is because of the following reasons: Although labor out-migration is at a large scale, a large part of such migration has been seasonal. In addition, labor migration has not yet resulted in rural depopulation at a large scale because the elderly parents and often also wife and children of the migrated laborer remain stay in the home village. As a consequence of the above two facts, virtually every household can continue to run agricultural activities, although in a reduced scale and intensity.

The extent of land fragmentation affecting cropland abandonment might be unique to China. As we mentioned in the introduction, a typical farming household in China manages only in total 0.56 ha of contracted land which is divided into 9.7 plots. The size per plot is far too small in comparison with household farming in other countries. Inappropriate plot sizes and scattered distribution of plots raise the costs of production significantly because producers cannot use large machinery and have to spend much time traveling between dispersed parcels. We note that a report in Albania also indicates that land fragmentation is a driver of cropland abandonment (Sikor et al., 2009). Nevertheless, the typical plot size in Albania is 1-2.5 ha, much bigger than cropland plots in China in general and in our mountainous case-study area in particular.

There is emerging a debate on whether land rental market in near future can reduce the extent of cropland abandonment. While village-level data of our research team support the view that intra-village land rental market does facilitate land circulation and consolidation, the plot-level data show that circulation and consolidation mainly take place among plots with higher productivity. This means that further research are needed for a better understanding of the functioning features of land rent market in mountain areas of China.

Our results have important policy implications. Given the fact that the rural-to-urban migration will be an irreversible process in mountainous areas of China during the coming decades, the marginalization of cropland in relatively less-favored locations will continue. In the meantime, aging of agricultural labor force will also continue, leading to a continuous reduction of effective labor supply to agriculture (Fan, 2003, 2004). Further studies are needed to simulate how the two trends will affect food security of China. Before that, policy makers have to confront very difficult choices between food security and ecological environment, especially the implementation of land consolidation projects and comprehensive agricultural development projects, which aims at food security, and water-soil protection projects, which aims at ecological environment. This study provides the modeling setting and key parameters for estimating spatially-explicit probability of 
cropland abandonment in the near future. Such a quantitative tool would help policy makers and land-use planners to identify the most attractive areas for promoting land consolidation projects and to identify the most vulnerable areas for water-soil preservation. In addition, our research suggests that on one hand, such government-led projects as land consolidation and comprehensive agricultural development projects should avoid agriculturally lessfavored mountainous areas characterized by steep slopes, shallow soils, prone to damage caused by wild-animals, and far away from residence of villagers. On the other hand, the specialized plantation project for fruit, tobacco and herbs can take the comparative advantage of mountainous areas.

\section{Acknowledgements}

The authors acknowledge the financial supports of the National Natural Science Foundation of China (grant no.: 41161140352) and International Institute for Applied systems Analysis (IIASA) in Austria.

\section{References}

Baumann, M., Kuemmerle, T., Elbakidze, M., Ozdogan, M., Radeloff, V.C., Keuler, N.S., Prishchepov, A.V., Kruhlov, I., Hostert, P., 2011. Patterns and drivers of post-socialist farmland abandonment in Western Ukraine. Land Use Policy 28, 552-562.

Benayas, J.R., Martins, A., Nicolau, J.M., Schulz, J.J., 2007. Abandonment of agricultural land: an overview of drivers and consequences. CAB Rev. 2, 1-14.

Benjamin, D., 1992. Household composition, labor markets, and labor demand: testing or separation in agricultural household models. Econometrica 60 (2), 287-322.

Blare, B., Hazell, P., Place, F., et al., 1992. The economics of farm fragmentation: evidence from Ghana and Rwanda. World Bank Econ. Rev. 6 (2), 233-254.

Bonet, A., Pausas, J.G., 2004. Species richness and cover along a 60-year chronosequence in old-fields of southeastern Spain. Plant Ecol. 174, 257-270.

Cai, F., Park, A., Zhao, Y., 2008. The Chinese Labor Market in the Reform Era in China's Great Economic Transformation. Cambridge University Press.

Díaz, G.I., Nahuelhual, L., Echeverría, C., Marín, S., 2011. Drivers of land abandonment in Southern Chile and implications for landscape planning. Landsc. Urban Plan. 99, 207-217.

DeLeo, J., 1993. Receiver operating characteristic laboratory ROCLAB: software for developing decision strategies that account for uncertainty. In: Proceedings of the Second International Symposium on Uncertainty, Modeling and Analysis, College Park, MD, USA, pp. 318-325.

Deng, X.Z., Huang, J.K., Rozelle, S., Uchida, E., 2006. Cultivated land conversion and potential agricultural productivity in China. Land Use Policy 23, 372-384.

Dong, X., 1996. Two-tier land tenure system and sustained economic growth in post-1978 rural China. World Dev. 24, 915-928.

Dubinin, M., Potapov, P., Lushchekina, A., Radeloff, V.C., 2010. Reconstructing long time series of burned areas in arid grasslands of southern Russia by satellite remote sensing. Remote Sens. Environ. 114, 1638-1648.

Dunn, R.R., 2004. Recovery of faunal communities during tropical forest regeneration. Conserv. Biol. 18, 302-309.

Elbakidze, M., Angelstam, P., 2007. Implementing sustainable forest management in Ukraine's Carpathian Mountains: the role of traditional village systems. For Ecol. Manag. 249, 28-38.

Fan, C.C., 2003. Rural-urban migration and gender division of labor in transitional China. Int. J. Urban Reg. Res. 27 (1), 24-47.

Fan, C.C., 2004. The state the migrant labor regime and maiden workers in China. Political Geogr. 23 (3), 283-305.

Feng, Z., Yang, Y., Zhang, Y., Zhang, P., Li, Y., 2005. Grain-for-green policy and its impacts on grain supply in West China. Land Use Policy 22, 301-312.

Fox, J., Fujita, Y., Ngidang, D., Peluso, N., Potter, L., Sakuntaladewi, N., Sturgeon, J., Thomas, D., 2009. Policies, political-economy, and swidden in Southeast Asia. Hum. Ecol. 37, 305-322.

Gallart, F., Llorens, P., 2003. Catchment management under environmental change: impact of land cover change on water resources. Water Int. 28, 334-340.

Gellrich, M., Baur, P., Koch, B., Zimmermann, N.E., 2007. Agricultural land abandonment and natural forest re-growth in the Swiss mountains: a spatially explicit economic analysis. Agric. Ecosyst. Environ. 118, 93-108.

Government of the People's Republic of China (GPRC), 2004. Land Administration Law of the People's Republic of China. The Standing Committee of the National People's Congress of the People's Republic of China, Beijing.

Groom, Ben, Grosjean, Pauline, Kontoleon, Andreas, Swanson, Timothy, Zhang, Shiqiu, 2010. Relaxing rural constraints: a 'win-win' policy for poverty and environment in China? Oxf. Econ. Pap. 62 (1), 132-156.

Höchtl, F., Lehringer, S., Konold, W., 2005. Wilderness: what it means when it becomes a reality-a case study from the southwestern Alps. Landsc. Urban Plan. 70, 85-95.
Hodges, J., 2006. Conservation of genes and culture: historical and contemporary issues. Poult. Sci. 85, 200-209.

Jiang, L., Deng, X., Seto, K.C., 2012. Multi-level modeling of urban expansion and cultivated land conversion for urban hotspot counties in China. Landsc. Urban Plan. 108, 131-139.

Keenleyside, C., Tucker, G.M., 2010. Farmland Abandonment in the EU: An Assessment of Trends and Prospects. Report Prepared for WWF. London Wwf \& Ieep.

Lambin, E.F., Meyfroidt, P., 2010. Land-use transitions: socio-ecological feedback versus socio-economic change. Land Use Policy 27, 108-118.

Li, X.B., Zhao, Y.L., 2011. Forest transition, agricultural land marginalization and ecological restoration. China Popul. Resour. Environ. 21, 91-95 (in Chinese).

Li, Y.C., Liu, C.X., Yuan, X.Z., 2009. Spatiotemporal features of soil and water loss in Three Gorges Reservoir Area of Chongqing. J. Geogr. Sci. 19 (1), 81-94.

Li, D., Chen, H., Hui, E.C., et al., 2014a. A real option-based valuation model for privately-owned public rental housing projects in China. Habitat Int. 43, $125-132$.

Li, Z., Yan, J., Hua, X., Xin, L., Li, X., 2014b. Factors influencing the cultivated land abandonment of households of different types: a case study of 12 typical villages in Chongqing Municipality. Geogr. Res. 33 (4), 721-734.

Lichtenberg, E., Ding, C., 2008. Assessing farmland protection policy in China. Land Use Policy 25, 59-68.

Lin, J.Y., 1997. The role of agriculture in the transition process of China. In: Kydd, J., Davidova, S., Mackay, M., Mech, T. (Eds.), The Role of Agriculture in the Transition Process Towards a Market Economy. UN/ECE Economic Studies No 9. United Nations, New York, NY, USA, pp. 63-75.

Liu, C.W., Li, X.B., 2005. The character and diagostic criterion for marginisation of the arable land. Prog. Geogr. 24, 106-113 (in Chinese).

Liu, J., Liu, M., Tian, H., Zhuang, D., Zhang, Z., Zhang, W., Tang, X., Deng, X., 2005 Spatial and temporal patterns of China's cropland during 1990-2000: an analysis based on Landsat TM data. Remote Sens. Environ. 98, 442-456.

Lu, L., Zhang, Y., Luo, T., 2014. Difficulties and strategies in the process of population urbanization: a case study in Chongqing of China. Open J. Soc. Sci. 2 (12), 90.

Pesqué-Cela, V., Tao, R., Liu, Y., Sun, L., 2009. Challenging, complementing or assuming 'the Mandate of Heaven'? Political distrust and the rise of self-governing social organizations in rural China. J. Comp. Econ. 37, 151-168.

Prishchepov, A.V., Müller, D., Dubinin, M., Baumann, M., Radeloff, V.C., 2013. Determinants of agricultural land abandonment in post-Soviet European Russia. Land Use Policy 30, 873-884.

Renwick, A., Jansson, T., Verburg, P.H., Revoredo-Giha, C., Britz, W., Gocht, A., McCracken, D., 2013. Policy reform and agricultural land abandonment in the EU. Land Use Policy 30, 446-457.

Rhemtulla, J.M., Mladenoff, D.J., Clayton, M.K., 2009. Legacies of historical land use on regional forest composition and structure in Wisconsin, USA (mid-1800-1930s-2000s). Ecol. Appl. 19, 1061-1078.

Schneider, L., Geoghegan, J., 2006. Land abandonment in an agricultural frontier after a plant invasion: the case of bracken fern in southern Yucatán, Mexico. Agric. Resour. Econ. Rev. 35, 167

Sikor, T., Müller, D., Stahl, J., 2009. Land fragmentation and cropland abandonment in Albania: implications for the roles of state and community in post-socialist land consolidation. World Dev. 37, 1411-1423.

Sileika, A.S., Stålnacke, P., Kutra, S., Gaigalis, K., Berankiene, L., 2006. Temporal and spatial variation of nutrient levels in the Nemunas River (Lithuania and Belarus). Environ. Monit. Assess. 122, 335-354.

Singh, I., Lyn, S., John, S., 1986. Agricultural Household Model: Extensions, Application and Policy. The Johns Hopkins University Press, Baltimore and London.

Solinger, D., 1999. Contesting Citzenship in Urban China: Peasant Migrants, the State, and the Logic of the Market. University of California Press, Berkeley.

Sun, G., Zhou, G., Zhang, Z., Wei, X., McNulty, S.G., Vose, J.M., 2006. Potential water yield reduction due to forestation across China. J. Hydrol. 328, 548-558.

Tan, M., Li, X., Xie, H., Lu, C., 2005. Urban land expansion and arable land loss in China-a case study of Beijing-Tianjin-Hebei region. Land Use Policy 22, 187-196.

Tian, Y., Li, X., Xin, L., Ma, G., Li, Z., 2009. Impacts of the rise of labor opportunity cost on agricultural land use changes: a case study of Ningxia Hui Autonomous region. J. Nat. Resour. 24, 369-377.

Tian, Y., Li, X., Ma, G., Hao, H., 2010. Influences of labor emigration from agriculture on the production abandonment of cultivated land in ecological sensitive areas. China Land Sci. 24, 4-9 (in Chinese).

Wang, J., Chen, Y., Shao, X., Zhang, Y., Cao, Y., 2012. Land-use changes and policy dimension driving forces in China: present, trend and future. Land Use Policy 29, 737-749.

Xu, J.Y., Chen, L.D., Lu, Y.H., Fu, B.J., 2007. Sustainability evaluation of the Grain for Green Project: from local people's responses to ecological effectiveness in Wolong Nature Reserve. Environ. Manag. 40 (1), 113-122.

Yan, H.M., Liu, J.Y., Huang, H.Q., Tao, B., Cao, M.K., 2009. Assessing the consequence of land use change on agricultural productivity in China. Global Planet. Change 67, 13-19.

Zhang, B.L., Yang, Q.Y., Yan, Y., Xue, M., Su, K.C., Zang, B., 2011. Characteristics and reasons of different households' farming abandonment behavior in the process of rapid urbanization based on a survey from 540 households in 10 counties of Chongqing Municipality. Resour. Sci. 33, 2047-2054 (in Chinese).

Zhang, Y., Li, X.B., Song, W., 2014. Determinants of cropland abandonment at the parcel, household and village levels in mountain areas of China: a multi-level analysis. Land Use Policy 41, 186-192. 